\title{
UbcH10 a Major Actor in Cancerogenesis and a Potential Tool for Diagnosis and Therapy
}

\author{
Ivan Presta ${ }^{1, *(\mathbb{C}}$, Fabiana Novellino ${ }^{2}{ }^{-}$, Annalidia Donato ${ }^{3}$, Domenico La Torre ${ }^{3}{ }^{-}$, \\ Caterina Palleria ${ }^{1}$, Emilio Russo ${ }^{1}$, Natalia Malara ${ }^{4}(\mathbb{D})$ and Giuseppe Donato ${ }^{1}$ \\ 1 Department of Health Sciences, University “Magna Græcia” of Catanzaro, 88100 Catanzaro, Italy; \\ palleria@unicz.it (C.P.); erusso@unicz.it (E.R.); gdonato@unicz.it (G.D.) \\ 2 Neuroimaging Unit, Institute of Bioimaging and Molecular Physiology, National Research \\ Council (IBFM-CNR) Viale Europa, 88100 Catanzaro, Italy; fabiana.novellino@cnr.it \\ 3 Department of Medical and Surgical Sciences, University “Magna Graecia” of Catanzaro, 88100 Catanzaro, \\ Italy; annalidia.donato@gmail.com (A.D.); dlatorre@unicz.it (D.L.T.) \\ 4 Department of Clinical and Experimental Medicine, University “Magna Graecia” of Catanzaro, \\ 88100 Catanzaro, Italy; nataliamalara@unicz.it \\ * Correspondence: presta@unicz.it
}

Received: 27 February 2020; Accepted: 15 March 2020; Published: 17 March 2020

\begin{abstract}
Malignant transformation is a multistep process in which several molecular entities become dysregulated and result in dysfunction in the regulation of cell proliferation. In past years, scientists have gradually dissected the pathways involved in the regulation of the cell cycle. The mitotic ubiquitin-conjugating enzymes $\mathrm{UbcH10}$, has been extensively studied since its cloning and characterization and it has been identified as a constantly overexpressed factor in many types of cancer. In this paper, we have reviewed the literature about UbcH10 in human cancer, pointing out the association between its overexpression and exacerbation of cancer phenotype. Moreover, many recalled studied demonstrated how immunohistochemistry or RT-PCR analysis can distinguish normal tissues and benign lesions from malignant neoplasms. In other experimental studies, many of the consequences of $\mathrm{UbcH} 10$ overexpression, such as increased proliferation, metastasizing, cancer progression and resistance to anticancer drugs are reversed through gene silencing techniques. In recent years, many authors have defined $\mathrm{UbcH} 10$ evaluation in cancer patients as a useful tool for diagnosis and therapy. This opinion is shared by the authors who advertise how it would be useful to start using in clinical practice the notions acquired about this important moleculein the carcinogenesis of many human malignancies.
\end{abstract}

Keywords: cancer; ubiquitin proteasome system; UbcH10; cell cycle control; therapy; gene silencing; immunohistochemistry; prognosis

\section{Introduction}

Ubiquitination-dependent proteolysis is related to various cellular processes including cell cycle progression, signal transduction, and differentiation. Ubiquitin $(\mathrm{Ub})$ is a small regulatory protein of 76 amino acids that is attached to other proteins as a post-translational regulatory event. The ubiquitylation of proteins that must be removed is carried out by a sequential cascade that involves three classes of enzymes: the ubiquitin-activating enzymes (E1s) create a thioester bond between a cysteine residue into the active site and the carboxyl end of ubiquitin, and then transfer it to another cysteine on ubiquitin-conjugating enzymes (E2s). The E2 enzymes, in turn, transfer the ubiquitin units to specific protein substrates, autonomously or engaging specific ubiquitin ligases (E3s) enzymes that probably help E2s to ensure the specificity of the substrate [1-3]. In the human genome, two genes coding 
for E1s, at least 38 genes encoding for E2s and about six hundred genes coding for E3s have been identified [4]. Modified substrate proteins are recognized and subsequently degraded by the $26 \mathrm{~S}$ proteasome, a multisubunit ATP-dependent protease complex, consisting of a cylindrical shaped $20 \mathrm{~S}$ core, capped on one or both sides by a $19 \mathrm{~S}$ regulatory particle $[5,6]$. The entire system is named ubiquitin proteasome system (UPS). Some components among these ubiquitin tagging enzymes arrays have become specialized to perform their function within the cell cycle regulation. The anaphase-promoting complex/cyclosome (APC/C) is a multisubunit complex being the main core an E3 ligase. By interacting with E2 $\mathrm{Ub}$ (intermediates, it catalyses polyubiquitination of key cell cycle regulators, inducing the metaphase/anaphase transition exit from mitosis, and maintenance of G1 [7]). It has been shown that in eukaryotes cells a specific ubiquitin-conjugating enzymes (E2) (UbcH10 in humans, coded by UBE2C gene) has a crucial role into the timer properties of APC/C. Moreover, in the early 2000s, it was observed that $\mathrm{UbcH10}$ is highly expressed in numerous cancerous cell lines and various primary tumors in comparison with surrounding normal tissues [8]. Since then, many studies have examined the expression of $\mathrm{UbcH} 10$ in many human tumors, highlighting its contribution in the mechanisms of carcinogenesis and assuming its usefulness in a diagnostic and therapeutic context. The aim of this work is to evaluate the state of the art of the knowledge about the impact of UbcH10 (over-)expression in cancer, and speculate on new diagnostic and therapeutic possibilities.

\section{The Role in Cell Cycle Regulation}

The run through the cell cycle is mainly based on the ordered and sequential activation of cyclin-depended kinases (CDKs) that, upon association with their partner cyclins, initiate crucial events and drive the transcription of genes important for cell cycle promotion. The timed activation of cyclin/CDK complexes is then mechanistically due to cyclins fluctuations, some of which are inducible by external stimuli (D-type cyclins), and others respond to internal mechanisms of induction (A-type and B-type cyclins), but all are promptly destroyed by ubiquitination and proteasomal degradation [9]. During the various phases of the cell cycle, several cyclins prevail to push the progression of a given phase or process and temporarily block the subsequent ones. Cyclin A is expressed from late G1 until prometaphase and its association with $\mathrm{Cdk} 1$ or $\mathrm{Cdk} 2$ leads to the inactivation of APC/C by inhibiting Cdh1 coactivator at the beginning of the S-phase $[10,11]$. Cyclin Ais, in turn, a substrate of APC/C that promotes its ubiquitinoylation and degradation from late G2. Subsequently, APC/C in its complete activation, promotes the degradation of securin, geminin, and cyclin B1, inducing sister chromatid separation and also promoting exit from mitosis [12-14]. In 1997, Townsley and co-workers cloned the human full-length complementary DNA (cDNA) for the UBE2C gene, the human homolog of clam E2-C type ubiquitin carrier protein and called it UbcH10 [15]. By using a dominant-negative mutant they demonstrated that the encoded protein is involved in the ubiquitin mediated degradation of cyclin A and cyclin B and then in the progression through mitosis [15].

Yamanaka and co-workers observed the ability of APC/C to regulate E2-C expression and proved in a mouse cell line, that $\mathrm{mE2}-\mathrm{C}$ is able to polyubiquitylate itself with the involvement of the cys 114 residue, into the active site [16]. This function, together with other mechanisms, as well as inhibition of the Cdh1 coactivator or expression of Emi1, are essential during G1 phase for switching the active APC/C into a cyclin A permissive state. Rape and Kirschner showed in human cell lines that cyclin A is stabilized in late G1, when instead the others APC/C substrates continue to be efficiently destroyed. This selectivity of substrates occurs only when the APC/C-specific ubiquitin conjugating enzyme (E2) $\mathrm{UbcH} 10$ is degraded in G1 until the prometaphase. UbcH10 in this way is eliminated at the M-G1 transition through ubiquitin mediated proteolysis [17].

\section{UbcH10 Studies in Various Types of Tumors}

Studies focusing on the role of $\mathrm{UbcH} 10$ in cancer have been conducted on human tissues by using immunohistochemical techniques, or in tumor-derived cell lines evaluating the UBE2C mRNA expression. Table 1 collects data from general literature. 
Table 1. List of significative papers about the role of $\mathrm{UbcH} 10$ in various cancers.

\begin{tabular}{|c|c|c|c|}
\hline Tumor/Organ & Methods & Syntesis Results & References \\
\hline \multirow{2}{*}{$\begin{array}{l}\text { Intracranial } \\
\text { meningioma }\end{array}$} & $\begin{array}{l}\text { Four primary meningioma cells } \\
\text { cultures and } \\
\text { Immunohistochemistry on tissue } \\
\text { samples. }\end{array}$ & $\begin{array}{l}\text { UbcH10 played an important role in the proliferation, } \\
\text { apoptosis, and progression of human meningioma cells. } \\
\text { RIZ1 regulated UbcH10 in a c-Myc dependent manner. }\end{array}$ & [18] \\
\hline & Immunohistochemistry. & $\begin{array}{l}\text { Nuclear and cytoplasm immunopositivity is observed in } \\
\text { advanced stages; low immunoreactivity in meningiomas } \\
\text { with low histological grade. } \\
\text { UbcH10 immunoreactivity significantly overexpressed in } \\
\text { meningioma patients with recurrence }(p<0.001) \text {. }\end{array}$ & [19] \\
\hline \multirow{2}{*}{ Glioma/Brain } & $\begin{array}{l}\text { Cell culture of astrocytic tumors } \\
\text { cells. } \\
\text { Immunohistochemistry on tissue } \\
\text { samples. }\end{array}$ & $\begin{array}{c}\text { Elevated expression levels of UbcH10 messenger RNA } \\
\text { (mRNA) in high- versus low-grade astrocytomas or } \\
\text { normal controls. } \\
\text { Immunohistochemistry shows increased UbcH10 in } \\
\text { high-grade astrocytomas versus low-grade tumors or } \\
\text { normal controls. }\end{array}$ & {$[20]$} \\
\hline & $\begin{array}{l}\text { Cell culture of U251 human } \\
\text { glioblastoma cells and small } \\
\text { interfering RNA (siRNA) } \\
\text { transfection. }\end{array}$ & $\begin{array}{l}\text { RNA interference targeting UbcH10 induces growth } \\
\text { inhibition, apoptosis, and cell cycle arrest of U251 cells. }\end{array}$ & [22] \\
\hline \multirow{3}{*}{ Carcinoma/Lung } & $\begin{array}{l}\text { NSCLC tumors and cell lines A549 } \\
\text { and SK-MES-1. }\end{array}$ & $\begin{array}{l}\text { Impairment of NSCLC cells growth through the } \\
\text { modulation of UbcH10 expression after hsa-miR661-3p } \\
\text { restoration. }\end{array}$ & [23] \\
\hline & Immunohistochemistry & $\begin{array}{l}\text { UbcH10 positivity in lung adenocarcinoma, squamous cell } \\
\text { carcinoma, large cell, and small cell carcinoma. } \\
\text { Progressive increase of UbcH10 levels associated to } \\
\text { decrease of tumor differentiation. Statistically significant } \\
\text { difference in UbcH10 positivity between grade I/III of lung } \\
\text { adenocarcinoma and squamous cell carcinoma. }\end{array}$ & [24] \\
\hline & $\begin{array}{l}\text { Immunohistochemistry } \\
\text { Cell culture and transfection of } \\
\text { siRNA. }\end{array}$ & $\begin{array}{c}\text { UbcH10 overexpression in poorly differentiated NSCLC } \\
\text { compared to well-differentiated ones. } \\
\text { Higher levels in squamous cell carcinoma than in } \\
\text { adenocarcinoma. } \\
\text { Higher UbcH10 expression associated with shorter } \\
\text { postoperative survival in NSCLC. } \\
\text { Inhibition of cell proliferation and } \\
\text { Increase of chemosensitivity after UbcH10 suppression in } \\
\text { SK-MES-1 cells. } \\
\text { Concomitant decrease of MDR1 gene expression. }\end{array}$ & [26] \\
\hline \multirow{3}{*}{ Carcinoma/Breast } & $\begin{array}{l}\text { Array of mRNA markers } \\
\text { expressed by circulating tumor } \\
\text { cells (CTCs). }\end{array}$ & $\begin{array}{l}\text { mRNA multimarker panel detected in CTCs from breast } \\
\text { cancer patients included UbcH10. }\end{array}$ & [27] \\
\hline & $\begin{array}{l}\text { Tissue micro-arrays } \\
\text { Immunohistochemistry } \\
\text { MB231; MDA468; MDA436; } \\
\text { MCF7; T47D and ZR 75-1 human } \\
\text { breast carcinoma cell lines. }\end{array}$ & $\begin{array}{l}\text { Association between high } \mathrm{UbcH} 10 \text { levels and ductal } \\
\text { histotype. } \\
\text { ErbB2 positivity and high Ki-67 staining. } \\
\text { siRNA mediated UbcH10 downregulation inhibits breast } \\
\text { carcinoma cell growth. }\end{array}$ & [28] \\
\hline & $\begin{array}{l}\text { Immunohistochemistry on cancer } \\
\text { tissues. } \\
\text { Molecular analysis in breast } \\
\text { cancer cell lines. }\end{array}$ & $\begin{array}{l}\text { Increased expression levels of UbcH10 in cancer, in } \\
\text { comparison with adjacent tissues. } \\
\text { UbcH10 mRNA and protein levels analysis in breast } \\
\text { cancer cell lines are significantly higher compared to } \\
\text { normal mammary epithelial cells. } \\
\text { The knockdown of UbcH10 inhibits proliferation of MCF-7 } \\
\text { and MCF-7/EPB/TXT cells increasing sensitivity to } \\
\text { chemotherapy drugs. }\end{array}$ & [29] \\
\hline
\end{tabular}


Table 1. Cont

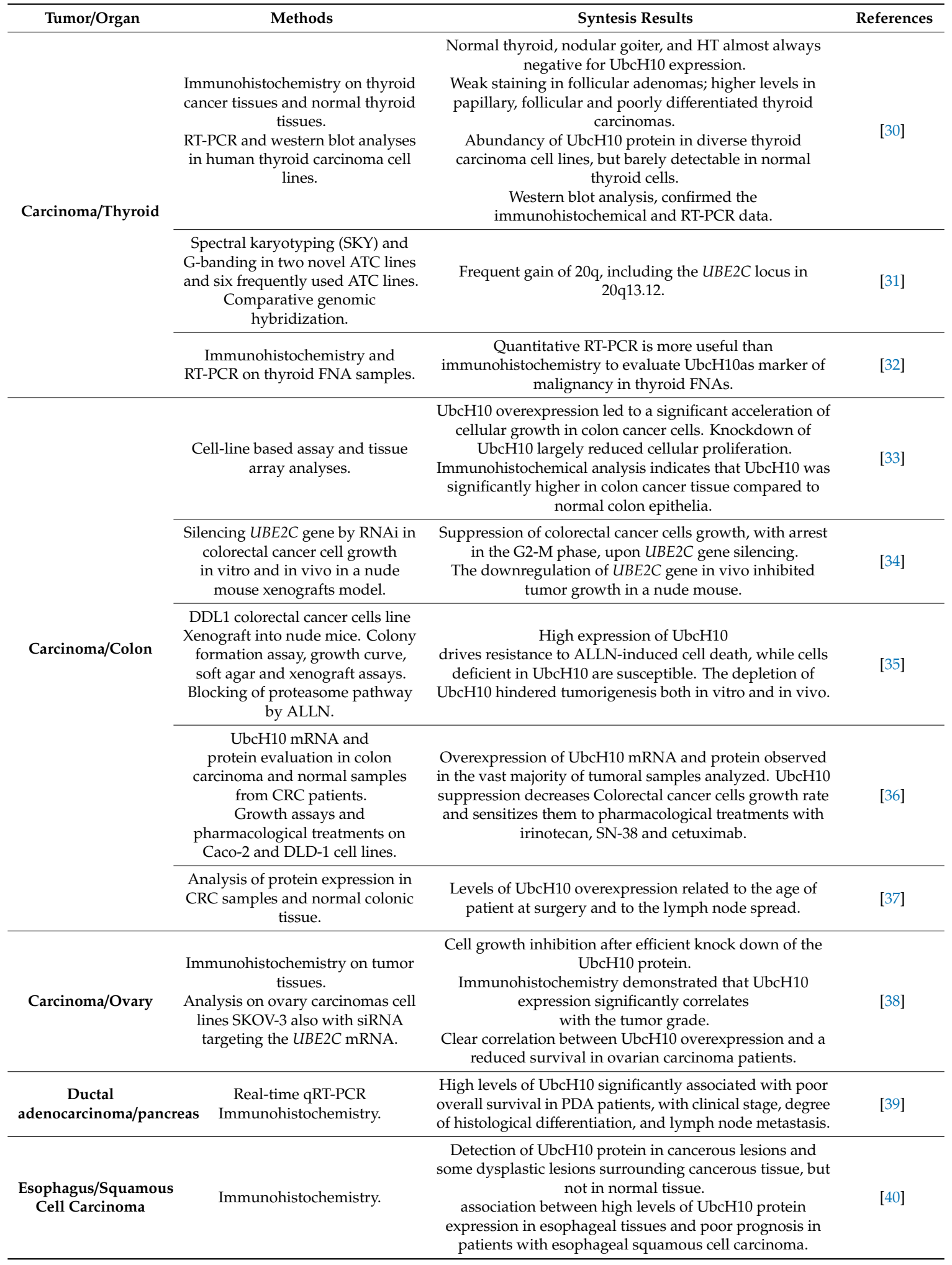


Table 1. Cont.

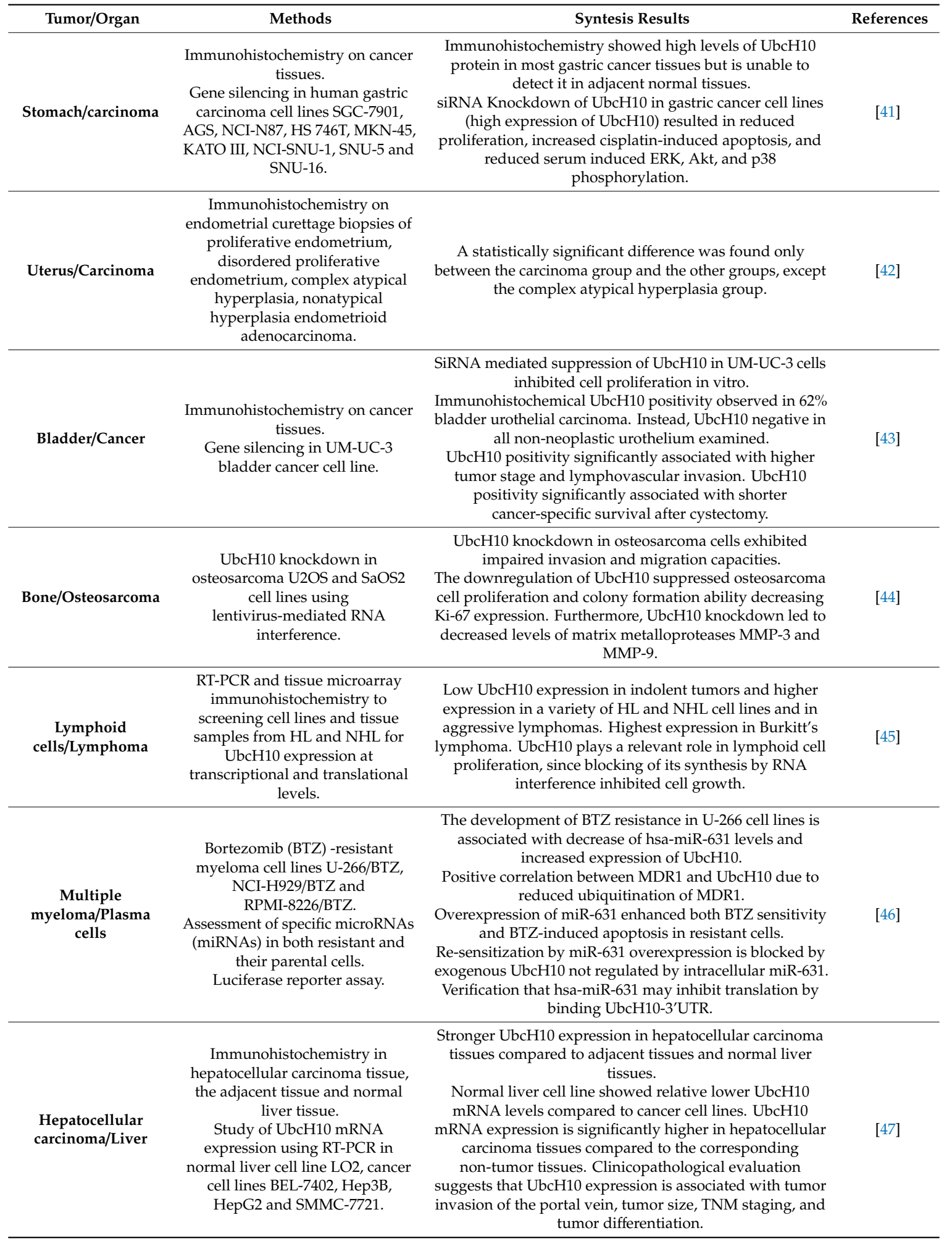

Abbreviations. RIZ1: Retinoblastoma protein-interacting zinc finger protein1; c-Myc: proto-oncogene c-Myc, NSCLC: non-small cell lung carcinomas, EGFR: epidermal growth factor receptor, p53: tumor suppressor p53, HT: Hashimoto's thyroiditis, HL: Hodgkin's lymphoma; NHL: non-Hodgkin's lymphoma; ATC: anaplastic thyroid carcinoma, FNA: fine-needle aspiration, CRC: colorectal cancer, PDA: Ductal adenocarcinoma of pancreas, BTZ: Bortezomib, TNM: TNM Classification of Malignant Tumors. 


\subsection{Brain Tumors}

Regarding brain tumors, there are studies on both meningiomas and gliomas. In meningiomas, high levels of $\mathrm{UbcH} 10$ appear to be associated with progression towards higher grades of malignancy and recurrence. The retinoblastoma protein-interacting zinc finger protein1 (RIZ1) is known to be an important tumor suppressor gene and negatively correlates with the pathological grade of meningioma and $\mathrm{UbcH} 10$ expression. It has been found in meningioma cells that RIZ1 is able to downregulate $\mathrm{UbcH} 10$ in a c-Myc-dependent manner and that provoked inhibitory on motility, invasion ability, and significantly increased the number of apoptotic cells [18,19]. The UbcH10 expression in astrocytic tumors is directly related to the tumor grade and no expression has been observed in normal tissue and gliosis. The expression levels of $\mathrm{UbcH} 10 \mathrm{mRNA}$ have been found elevated in high-grade versus low-grade astrocytomas or normal controls [20,21]. Furthermore, it has been shown that RNA interference (RNAi) targeting $\mathrm{UbcH10}$ induced growth inhibition, apoptosis, and cell cycle arrest in U-251 glioblastoma cell line, proving the important role for $\mathrm{UbcH} 10$ in the regulation of proliferation, apoptosis, and cell cycle progression of glioma cells [22].

\subsection{Lung Cancer}

UbcH10 expression has been mainly explored in non-small cell lung carcinomas (NSCLC). In samples from poorly differentiated NSCLC, UbcH10 was overexpressed compared to well-differentiated ones. In particular, the expression levels were significantly higher in squamous cell carcinoma than in adenocarcinoma. It has been found that higher UbcH10 expression is associated with a shorter postoperative survival in NSCLC patients. Moreover, UbcH10 expression directly correlates with the mutational status of p53 while the correlation is inverse with that of EGFR [24,25]. Interestingly, in the lung, squamous cell carcinoma-derived SK-MES-1 cells line the suppression of UbcH10 inhibited cell proliferation, increased chemosensitivity to gemcitabine or paclitaxel, and downregulated the expression $A B C B 1$ gene encoding for the integral membrane-associated protein, named Multidrug Resistance Protein 1, which is involved in extra- and intra-cellular membrane transport [26]. Finally, it has recently demonstrated that hsa-miR661-3p microRNA overexpression is able to decrease the growth rate in NSCLC through the downregulation of UbcH10 expression [23].

\subsection{Breast Cancer}

The UbcH10 protein was initially included in a high sensitivity and specific multimarker assay for the detection of circulating tumor cells (CTCs) in breast cancer patients [27]. Since then, there have been important progresses in breast cancer CTCs analysis, but in recent times the attention on UbcH10 involvement has declined $[48,49]$. Some studies based on tissue micro-arrays immunohistochemistry and human breast carcinoma-derived cell lines, have shown that high UbcH10 expression levels are associated with ductal histotype. These studies also showed ErbB2 immunoreactivity and high levels of Ki-67 staining in tumor tissues. In cell lines models, it has been shown that the specific small interfering RNAs (siRNAs)-mediated blocking of ErbB2 is able to downregulate the UbcH10 expression and significantly decreased the breast carcinoma cell growth [28]. The analysis of UbcH10 mRNA and protein content, analyzed in five breast cancer cell lines, confirmed that UbcH10 expression is significantly higher in comparison with normal mammary epithelial cells. Furthermore, the UbcH10 downregulation decreased the proliferation rate both in MCF-7 and in the epirubicin/docetaxel resistant cell line MCF-7/EPB/TXT cells, and in this last, also increased the epirubicin and docetaxel-induced apoptosis [29].

\subsection{Thyroid Cancer}

In thyroid cancer, it has been found that the $\mathrm{UbcH} 10$ protein is abundantly expressed in many thyroid carcinoma-derived cell lines, such as TPC-1, WRO, NPA, ARO, FRO, NIM 1, B-CPAP, FB-1, Kat-4 and Kat-18, whereas the protein levels are barely detectable in normal thyroid cells [30]. The expression 
of UbcH10 has been also analyzed in normal and neoplastic thyroid tissues by immunohistochemistry, revealing that normal thyroid, nodular goiter, and Hashimoto's thyroiditis (HT) were almost always completely negative for $\mathrm{UbcH} 10$ expression. A weak staining was detectable in follicular adenomas and higher levels of $\mathrm{UbcH} 10$ were recorded in papillary (median value $2.2 \%$ of positive cells; range $0.9 \%-4.1 \%$ ), follicular (median value $2.8 \%$ of positive cells; range $1 \%-6.1 \%$ ) and poorly differentiated (median value $10.4 \%$ of positive cells; range $8 \%-14.9 \%$ ) carcinomas. Mainly, the immunoreactivity signal has been always easily detectable in the nuclei of scattered neoplastic cells. Western blot analysis, performed on surgically removed thyroid tumors, confirmed the immunohistochemical data and RT-PCR analysis results [30]. Spectral karyotyping (SKY), G-banding and comparative genomic hybridization carried out in two novel anaplastic thyroid carcinoma (ATC) cell lines and in six frequently used ATC cell lines, detected a frequent gain of 20q, including the UBCH10 gene locus in 20q13.12 [31]. Interestingly, the amplification of the long arm of chromosome 20 has been frequently observed in many types of cancer in which an overexpression of UbcH10 is reported [50]. Finally, the analysis of $\mathrm{UbcH} 10$ in thyroid fine-needle aspiration (FNA) by quantitative RT-PCR is more useful than immunohistochemistry to increase the detection of malignancy in thyroid [32].

\subsection{Gastroenteric Tumors}

Immunohistochemical data obtained in squamous cells carcinoma of esophagus confirmed the general prognostic impact of $\mathrm{UbcH} 10$ evaluation in cancers. UbcH10 protein was detected in cancerous lesions and some dysplastic lesion, surrounding cancerous tissue, but not in normal tissue. Moreover, in patients with esophageal squamous cell carcinoma a significant association between high levels of UbcH10 protein and poor prognosis has been demonstrated [40].

High UbcH10 protein levels have also seen in gastric cancer tissues by immunohistochemistry in many cases and again, in adjacent normal tissues this protein was undetectable. Furthermore, studies on human gastric carcinoma cell lines such as SGC-7901, AGS, NCI-N87, HS 746T, MKN-45, KATO III, NCI-SNU-1, SNU-5, and SNU-16 demonstrated that siRNA-mediated knockdown of UbcH10 expression in gastric cancer cells reduced proliferation rate, increased cisplatin-induced apoptosis and decreased serum-induced ERK, Akt/PKB and p38 phosphorylation [41].

In colon cancer, all performed studies confirmed the importance of overexpression of $\mathrm{UbcH} 10$ in the process of tumorigenesis. In fact, the overexpression of UbcH10 in the DLD-1 colon cancer cell line led to a significant acceleration of cellular proliferation reducing the doubling times. Consistently, the UbcH10 knockdown, obtained by using specific siRNA, largely reduced cellular proliferation. Immunohistochemical tissue array analysis indicated that $\mathrm{UbcH} 10$ was significantly higher in colon cancer tissue compared to normal colon epithelia [33]. By using a short hairpin RNA expression cassette, containing a UbcH10 RNAi, it has been obtained the gene silencing in two colon cancer cell lines and, in vivo, in a nude mouse xenograft. In this work, cell growth was markedly suppressed, arresting in the G2-M phase. Moreover, the inhibition of tumour growth in the nude mice xenograft model has been obtained showing a therapeutic potential for targeting $\mathrm{UbcH10}$ in colon cancer [34]. Other similar studies, in vitro and in vivo, employed the DDL-1 cells line and xenografts into nude mice and evaluated effects on proliferation by colony formation, growth curve, soft agar assay, and growth of xenograft implantation. The effect of blocking proteasome pathway by using N-acetyl-Leu-Leu-Norleu-al (ALLN) was also examined. Interestingly, high expression of $\mathrm{UbcH} 10$ drives resistance to ALLN-induced cell death, while cells deficient in $\mathrm{UbcH} 10$ are susceptible to ALLN-induced cell death. The depletion of UbcH10 hindered tumorigenesis, both in vitro and in vivo [35]. In a series of normal colon and colon carcinoma samples, collected from surgical specimens, $\mathrm{UbcH} 10 \mathrm{mRNA}$ and protein expression levels have been evaluated. The overexpression of $\mathrm{UbcH} 10 \mathrm{mRNA}$ and protein has been observed in the vast majority of patients analyzed. Moreover, the $\mathrm{UbcH} 10$ suppression analyzed in vitro study in Caco-2 and DLD-1 cell lines, decreases growth rate and sensitized them to pharmacological treatments with irinotecan, its active metabolite SN-38 and cetuximab [36]. Analysing the expression of UbcH10 protein in a series of colorectal cancer samples, matched with the corresponding normal tissue, obtained from 
elderly patients, it has been observed that the overexpression of $\mathrm{UbcH} 10$ is attenuated in relation to the patient's age at surgery. Higher levels of UbcH10 overexpression were concentrated around 60 years of age, whereas it tended to lower in the groups of 70 and 80 years; in the same work, it has been also found that $\mathrm{UbcH} 10$ protein overexpression is related to the lymph node spread, as evaluated by $\mathrm{N}$ stage. Since the expression of $\mathrm{UbcH} 10$ predicts response to cetuximab, regardless of ras status, it would be worthy testing CRC patients also for UbcH10, prior to start treatments, and consider silencing UbcH10 as coadjuvant [37].

\subsection{Gynecologic Tumors}

In ovarian carcinomas, immunohistochemical studies demonstrate that $\mathrm{UbcH} 10$ expression significantly correlates with the tumor grade and the undifferentiated histotype. A clear correlation between $\mathrm{UbcH} 10$ overexpression and reduced survival in patients with ovarian carcinoma has been described and the indication of $\mathrm{UbcH} 10$ as a valid prognostic marker in this neoplastic disease has brought forth. The SKOV-3 cell line of ovary carcinoma has been treated with siRNA duplexes targeting the UbcH10 mRNA. After transfection, it was observed an efficient knock down of the UbcH10 protein levels. The cell growth analysis, in the presence or absence of siRNA duplexes, revealed that blocking UbcH10 protein synthesis, significantly inhibits ovarian carcinoma cell growth [38]. The UbcH10 expression has been studied in endometrial lesions by immunohistochemistry in curettage material. A statistically significant difference was found between a carcinoma group and other groups of benign lesions, such as proliferative endometrium, disordered proliferative endometrium, and non-atypical hyperplasia. Only differences with complex atypical hyperplasia group did not reach a statistically difference. Data collected in this tissue micro array-based studies, also in these cases, encourage to use $\mathrm{UbcH10}$ as a diagnostic marker in histopathology [42].

\subsection{Pancreas and Liver}

Ductal adenocarcinoma of pancreas (PDA) is another solid neoplasm in which UbcH10 plays a pivotal role in tumorigenesis and clinical evolution of disease. Immunohistochemistry and RT-PCR showed that high expression of $\mathrm{UbcH} 10$ was significantly associated with poor overall survival in PDA patients. High expression of $\mathrm{UbcH10}$ was also significantly correlated with the clinical stage, the degree of histological differentiation, and the presence of lymph node metastasis [39]. Hepatocellular carcinoma (HCC) has been studied for UbcH10 expression both in cancer and normal tissues. Several studies have been carried out in normal liver-derived cell line LO2 and cancer derived cell lines BEL-7402, Hep3B, HepG2, and SMMC-7721. Immunohistochemistry analyses identified stronger UbcH10 expression in hepatocellular carcinoma tissues compared to the adjacent tissues and normal liver tissue. Normal liver cell line showed significantly lower UbcH10 mRNA expression levels compared to the liver cancer derived cell lines. Moreover, UbcH10 mRNA expression levels were significantly higher in hepatocellular carcinoma tissues compared to the surrounding non-tumor tissues. Clinicopathological evaluation suggested that $\mathrm{UbcH} 10$ expression is associated with tumor invasion of the portal vein, tumor size, TNM staging, and tumor differentiation [51].

\subsection{Other Neoplasms}

Immunohistochemical studies in bladder cancer, allowed to observe UbcH10 positivity in $62 \%$ of bladder urothelial carcinoma cases treated with radical cystectomy. Instead, UbcH10 was undetectable in all non-neoplastic urothelium examined. UbcH10 positivity is significantly associated with higher tumor stage and presence of lymphovascular invasion. In addition, positivity has been also significantly associated with shorter cancer-specific survival after cystectomy [43].

In regard to studies of UbcH10 expression in bone osteosarcoma, the UbcH10 knockdown has been obtained in osteosarcoma derived U2OS and SaOS2 cell lines by using lentivirus-mediated RNA interference. The osteosarcoma cells that underwent to UbcH10 knockdown exhibited impaired invasion and migration capabilities. The downregulation of $\mathrm{UbcH} 10$ also suppressed osteosarcoma 
cell proliferation and colony formation ability decreasing Ki-67 expression. Furthermore, knockdown of $\mathrm{UbcH} 10$ led to decreased levels of extracellular matrix metalloproteinases [44].

RT-PCR and tissue microarray immunohistochemistry-based studies have been performed in a group of various type lymphomas. Cell lines and tissue samples both from Hodgkin's (HL) 1 and of non-Hodgkin's lymphoma (NHL) were assayed for UbcH10 expression at transcriptional and translational levels. UbcH10 expression has been found to be relatively low in indolent tumors and higher in a variety of aggressive lymphomas and HL- and NHL-derived cell lines. The highest levels were found in Burkitt's lymphoma. UbcH10 expression plays a relevant role in lymphoid cell proliferation, since blocking its synthesis by RNA interference, inhibits cell growth [45]. Multiple myeloma is a pathology in which proteasome inhibitors have an important efficacy in the treatment. Recently it has been observed that $\mathrm{UbcH} 10$ is highly expressed in Bortezomib (BTZ)-resistant myeloma cell lines U-266/BTZ, NCI-H929/BTZ and RPMI-8226/BTZ evaluated in a gradient of BTZ increasing concentrations. In these cell lines it has been observed that during the development of BTZ resistance, the hsa-miR-631 levels are decreased and coherently the expression of the target gene UbcH10 increased [46].

\section{Discussion}

Taking into account the review of studies presented above, it appears extremely clear how the $\mathrm{UbcH} 10$ mitotic ubiquitin conjugating enzyme is a crucial common factor in the carcinogenesis process in many tumors (Figure 1).

Increased levels in mRNA and protein expression are well documented in most studies. As it has been shown in the diverse studies where the modulation of its expression is obtained, $\mathrm{UbcH} 10$ plays an essential role in the proliferation of cancer cells and probably in the progression of malignancies. In general, the immunohistochemical proofs about protein expression on tumor tissue samples correlates with the proliferative index and the degree of the neoplasms. Moreover, UbcH10 overexpression has been associated in transgenic mouse models, with distortions in cell division mechanics, such as supernumerary centrioles, lagging chromosomes, and aneuploidy [52]. The mechanisms by which $\mathrm{UbcH} 10$ is overexpressed in all various types of cancer are not fully understood. The hypothesis of the amplification of $20 \mathrm{q}$ chromosomal region, containing the UBE2C locus, is roughly obvious but is confirmed in studies carried out in colorectal and gastric cancer from microarray datasets and cancer cell lines. The gain of copy number on 20q almost always resulted in chromosomal instability [53,54]. Consistent with these findings, UBE2C has been included in the CIN25 chromosomal instability signature during a study employing several YAP-driven murine cell lines of cholangiocarcinoma [55]. Given this strong association between the gene amplification, or in any case the overexpression, of $\mathrm{UbcH} 10$ and the genomic instability observed in many types of cancer, it is reasonable that the positive selection of the $\mathrm{UbcH} 10$ hyper-expressing clones is a crucial event in the process of malignant transformation. It is probably one of the genes that promotes and supports heterogeneity in cancer cell populations with which poor prognosis and drug resistance are associated. The occurrence of other mechanisms, such as the control of gene expression based on epigenetics patterns, remains only a hypothetical and unexplored possibility. Many authors thought that the assessment of UbcH10 expression could be a useful diagnostic, prognostic and therapy-orienting tool. In fact, the immunohistochemical detection well characterizes only the neoplastic tissues, but not the corresponding normal tissues. Parallel data, coming from studies on mRNA levels, retraced the same expression profiles for neoplastic tissues. These results have been often correlated with clinical parameters, such as patient survival and disease staging. Regarding the possible therapeutic significance, the expression of $\mathrm{UbcH} 10$ has been shown to be a possible factor of resistance to therapy with certain drugs, including proteasome inhibitors. Initially, proteasome inhibitors were developed to prevent cancer-related cachexia and the first to be approved was bortezomib in 2003. At therapeutic doses, bortezomib inhibits approximately $30 \%$ of proteasome-mediated protein degradation [56], which is sufficient to induce tumor cell apoptosis without producing toxicity in noncancer cells. As aforementioned, recently, $\mathrm{Xi}$ 
and colleagues demonstrated, for the first time, that UbcH10 is highly expressed in three bortezomib (BTZ)-resistant multiple myeloma cell lines, which is attributed to the inactivation of post-transcriptional control. In particular, data revealed that during the development of bortezomib resistance in cells, the hsa-miR-631 levels were decreased, resulting in an increase of UBE2C gene expression. Furthermore, data showed that the multiple drug-resistant protein MDR1 exhibited a positive correlation with $\mathrm{UbcH} 10$ levels and researchers hypothesized the presence of a miR-631/UbcH10/MDR1 pathway during the development of BTZ resistance in multiple myeloma. However, in this study, it is not shown that the increased MDR1 protein stability is a direct effect of altered ubiquitination rate, eventually due to the $\mathrm{UbcH} 10$ overexpression and the actual mechanism of this association should be elucidated [46]. The mechanism by which proteasome inhibitors lead to cell death affects several pathways involved in cancer. One supposed cytotoxicity mechanism is represented by the inhibition of the pro-survival NF- $\mathrm{KB}$ pathway for several cell types, in particular for hematopoietic lineages. The endogenous NF- $\mathrm{kB}$ protein inhibitor $I \kappa B \alpha$ is degraded by the proteasome and its degradation is necessary for the p50/p65 NF- $\mathrm{KB}$ transcription factors to become active and translocate to the nucleus [57]. All proteasome inhibitors primarily target the chymotrypsin-like, $\beta 5$ subunit or, if used at higher concentrations, also block the trypsin-like ( $\beta 2)$ and caspase-like ( $\beta 1)$ subunits as well. More effective tools acting on this system are expected to increase efficacy in cancer therapy. There must be more specific UPS inhibitors targeting the core of ubiquitination's specificity that reside in E2s or E3s components of the UPS system. A recent promising attempts have been made recently to target E1 enzymes [58], but the turning point could come from the studies about conjugating enzymes an ligases [59-63], hoping to get a specific inhibitor for UbcH10 to be placed alongside the specific siRNA or microRNA (miRNA) used so far. So far, only one study has been carried out to search for specific UbcH10 inhibitors but has stopped in the selection from ligand libraries identifying two candidate compounds that are waiting to be tested in vitro [64]. We would expect to emulate the results obtained with inhibitors of other E2 enzymes, such as in the case of small molecule inhibitor SMI \# 9 for Rad6 in triple negative breast cancer. This molecule, beyond the problems faced in conveying the drug, has been shown to induce cytotoxicity in breast cancer cells but spares normal breast cells and demonstrated efficacy in combination with cisplatin [65]. In our opinion, the data accumulated in recent years concerning UbcH10 are solid and promising, and should not be forgotten. They show that UbcH10 has the potential for playing a pivotal role both as cancer marker and pharmacological target. By the way, the features of a so specific molecular marker must be exploited, integrating its detection with the rapidly developing techniques for the study of CTCs and circulating tumor nucleic acids; that can be combined with minimal invasiveness of liquid biopsy. The UbcH10 overexpression could be investigated directly on CTCs by immunocytochemical approaches, as demonstrated for other biomarkers [66-69], or by searching for its transcript in cell free circulating RNA in biological fluids. As it has been shown by recent, encouraging data from a study carried out on the urine of subjects with breast cancer [70], the analysis of UBE2C transcript levels could become a sensitive marker that can be exploited in diagnostics. More studies should be designed and performed in the near future to test the real power of what could be an exceptional tool for diagnostics and clinical practice. 


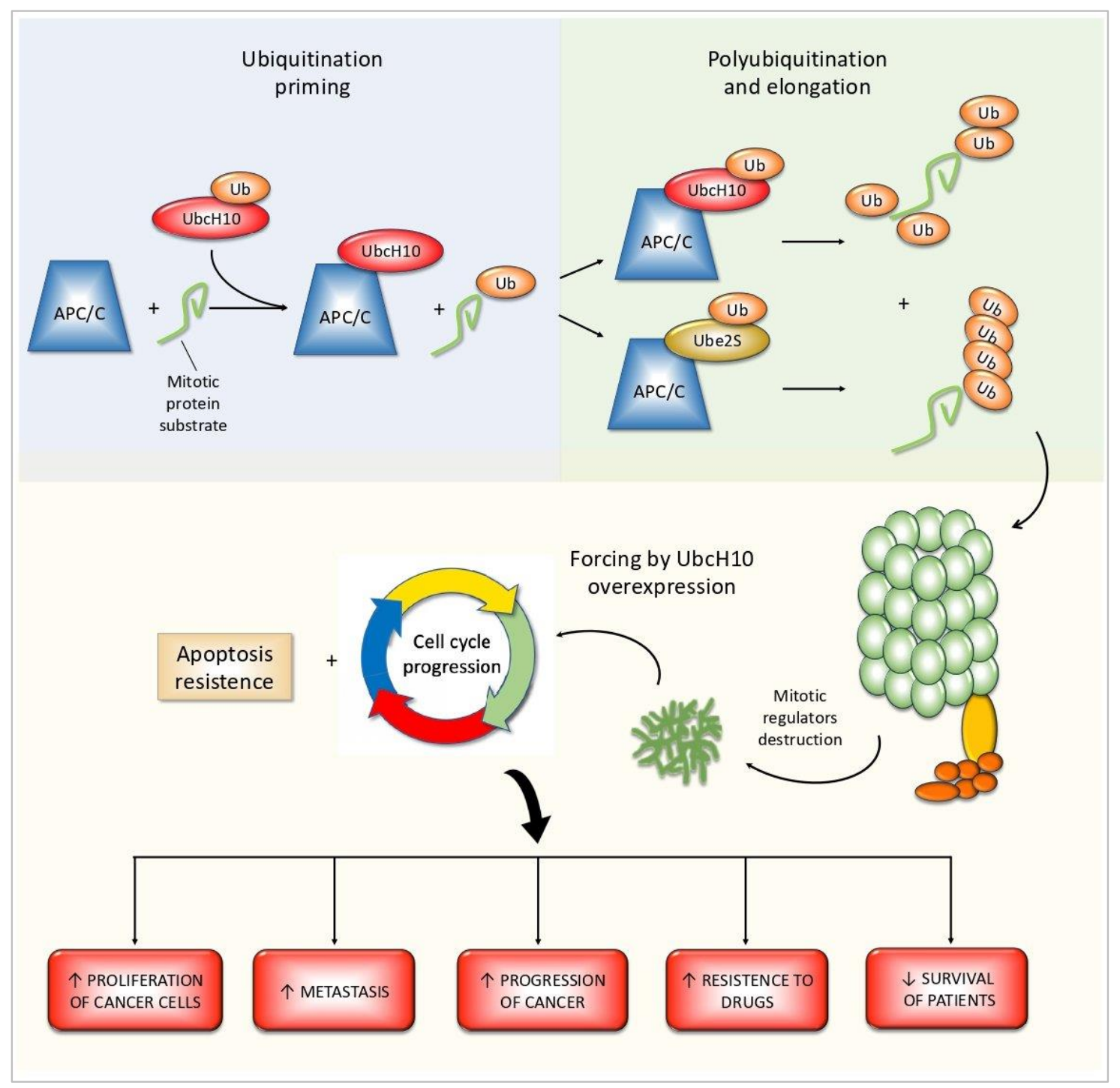

Figure 1. UbcH10 is together with Ube2S, the ubiquitin-conjugating enzymes (E2) partner of anaphase-promoting complex/cyclosome (APC/C) ubiquitin ligases (E3) complex. UbcH10 is devoted to ubiquitination priming and multi ubiquitination, while Ube2S presides to further ubiquitin chain elongation. $\mathrm{UbcH} 10$ overexpression has been detected in samples of diverse solid tumors or hematologic cancers as well as in experimental models. Experimental silencing of UBE2C mRNA levels allowed to find a link between its overexpression and worsening of malignant characteristics.

Author Contributions: Conceptualization, G.D. and I.P.; writing and original draft preparation, G.D., I.P., E.R., C.P., and F.N.; writing-review and editing, I.P., N.M., D.L.T., A.D., E.R., and F.N.; image assembly, F.N., and G.D.; supervision, F.N., G.D., and I.P. All authors have read and agreed to the published version of the manuscript.

Funding: This research received no external funding.

Conflicts of Interest: The authors declare no conflict of interest. 


\section{Abbreviations}

$\begin{array}{ll}\text { ABCB1 } & \text { ATP binding cassette subfamily B member 1 } \\ \text { Akt/PKB } & \text { AKT Serine/Threonine Kinase 1 } \\ \text { ALLN } & \text { N-acetyl-Leu-Leu-Norleu-al } \\ \text { APC/C } & \text { Anaphase-promoting complex/cyclosome } \\ \text { ATC } & \text { Anaplastic thyroid carcinoma } \\ \text { BTZ } & \text { Bortezomib } \\ \text { Cdh1 } & \text { APC coactivator Cdh1 } \\ \text { CdK1 } & \text { Cyclin-dependent kinase 1 } \\ \text { CdK2 } & \text { Cyclin dependent kinase 2 } \\ \text { CDKs } & \text { Cyclin-depended kinases } \\ \text { c-Myc } & \text { Avian myelocytomatosis viral oncogene homolog } \\ \text { CTCs } & \text { Circulating tumor cells } \\ \text { E1s } & \text { Ubiquitin-activating enzymes } \\ \text { E2s } & \text { Ubiquitin-conjugating enzymes } \\ \text { E3s } & \text { Ubiquitin ligases } \\ \text { EGFR } & \text { Epidermal growth factor receptor } \\ \text { ErbB2 } & \text { Erb-b2 receptor tyrosine kinase 2 } \\ \text { ERK } & \text { Extracellular regulated MAP kinase } \\ \text { E2 Ub } & \text { E2 enzyme and ubiquitin conjugated by thioester bond } \\ \text { FNA } & \text { Fine-needle aspiration } \\ \text { HCC } & \text { Hepatocellular carcinoma } \\ \text { HL } & \text { Hodgkin's lymphoma } \\ \text { hsa-miR-631 } & \text { microRNA 631 } \\ \text { hsa-miR661-3p } & \text { microRNA 661 } \\ \text { NF-kB } & \text { Nuclear factor kappa B subunit } \\ \text { NHL } & \text { non-Hodgkin's lymphoma } \\ \text { NSCLC } & \text { non-small cell lung carcinomas } \\ \text { p38 } & \text { Mitogen-activated protein kinase p38 } \\ \text { p53 } & \text { Tumor suppressor p53 } \\ \text { RIZ1 } & \text { Retinoblastoma protein-interacting zinc finger protein1 } \\ \text { RNAi } & \text { RNA interference } \\ \text { qRT-PCR } & \text { Quantitative real time polymerase chain reaction } \\ \text { siRNA } & \text { Small interfering RNA } \\ \text { SKY } & \\ \text { UPS } & \text { Spetral karyotyping } \\ & \end{array}$

\section{References}

1. Ye, Y.; Rape, M. Building ubiquitin chains: E2 enzymes at work. Nat. Rev. Mol. Cell Biol. 2009, 10, 755-764. [CrossRef] [PubMed]

2. Scheffner, M.; Nuber, U.; Huibregtse, J.M. Protein ubiquitination involving an E1-E2-E3 enzyme ubiquitin thioester cascade. Nature 1995, 373, 81-83. [CrossRef] [PubMed]

3. Brown, N.G.; VanderLinden, R.; Watson, E.R.; Weissmann, F.; Ordureau, A.; Wu, K.-P.; Zhang, W.; Yu, S.; Mercredi, P.Y.; Harrison, J.S.; et al. Dual RING E3 Architectures Regulate Multiubiquitination and Ubiquitin Chain Elongation by APC/C. Cell 2016, 165, 1440-1453. [CrossRef] [PubMed]

4. Deshaies, R.J.; Joazeiro, C.A.P. RING Domain E3 Ubiquitin Ligases. Annu. Rev. Biochem. 2009, 78, 399-434. [CrossRef] [PubMed]

5. Glickman, M.H.; Ciechanover, A. The ubiquitin-proteasome proteolytic pathway: Destruction for the sake of construction. Physiol. Rev. 2002, 82, 373-428. [CrossRef] [PubMed]

6. Leestemaker, Y.; Ovaa, H. Tools to Investigate the Ubiquitin Proteasome System. Available online: https: //pubmed.ncbi.nlm.nih.gov/?term=Tools+to+investigate+the+ubiquitin+proteasome+system (accessed on 19 February 2020).

7. Primorac, I.; Musacchio, A. Panta rhei: The APC/C at steady state. J. Cell Biol. 2013, 201, 177-189. [CrossRef] 
8. Okamoto, Y.; Ozaki, T.; Miyazaki, K.; Aoyama, M.; Miyazaki, M.; Nakagawara, A. UbcH10 is the cancer-related E2 ubiquitin-conjugating enzyme. Cancer Res. 2003, 63, 4167-4173.

9. Poon, R.Y.C. Cell cycle control: A system of interlinking oscillators. Methods Mol. Biol. 2016, 1342, 3-19.

10. Lukas, C.; Sørensen, C.S.; Kramer, E.; Santoni-Ruglu, E.; Lindeneg, C.; Peters, J.M.; Bartek, J.; Lukas, J. Accumulation of cyclin B1 requires E2F and cyclin-A-dependent rearrangement of the anaphase-promoting complex. Nature 1999, 401, 815-818. [CrossRef]

11. Pagano, M.; Pepperkok, R.; Verde, F.; Ansorge, W.; Draetta, G. Cyclin A is required at two points in the human cell cycle. EMBO J. 1992, 11, 961-971. [CrossRef]

12. Geley, S.; Kramer, E.; Gieffers, C.; Gannon, J.; Peters, J.M.; Hunt, T. Anaphase-promoting complex/cyclosome-dependent proteolysis of human cyclin A starts at the beginning of mitosis and is not subject to the spindle assembly checkpoint. J. Cell Biol. 2001, 153, 137-147. [CrossRef] [PubMed]

13. Elzen Den, N.; Pines, J. Cyclin A is destroyed in prometaphase and can delay chromosome alignment and anaphase. J. Cell Biol. 2001, 153, 121-135. [CrossRef] [PubMed]

14. Peters, J.M. The anaphase-promoting complex: Proteolysis in mitosis and beyond. Mol. Cell 2002, 9, 931-943. [CrossRef]

15. Townsley, F.M.; Aristarkhov, A.; Beck, S.; Hershko, A.; Ruderman, J.V. Dominant-negative cyclin-selective ubiquitin carrier protein E2-C/UbcH10 blocks cells in metaphase. Proc. Natl. Acad. Sci. USA 1997, 94, 2362-2367. [CrossRef] [PubMed]

16. Yamanaka, A.; Hatakeyama, S.; Kominami, K.I.; Kitagawa, M.; Matsumoto, M.; Nakayama, K.I. Cell cycle-dependent expression of mammalian E2-C regulated by the anaphase-promoting complex/cyclosome. Mol. Biol. Cell 2000, 11, 2821-2831. [CrossRef]

17. Rape, M.; Kirschner, M.W. Autonomous regulation of the anaphase-promoting complex couples mitosis to S-phase entry. Nature 2004, 432, 588-595. [CrossRef]

18. Cai, Z.; Zou, Y.; Hu, H.; Lu, C.; Sun, W.; Jiang, L.; Hu, G. RIZ1 negatively regulates ubiquitin-conjugating enzyme E2C/UbcH10 via targeting c-Myc in meningioma. Am. J. Transl. Res. 2017, 9, 2645-2655.

19. Jiang, L.; Wang, T.; Bao, Y.; Qian, J.; Wu, X.J.; Hu, G.H.; Lu, Y.C. A study of UbcH10 expression and its association with recurrence of meningiomas. J. Surg. Oncol. 2012, 106, 327-331. [CrossRef]

20. Jiang, L.; Huang, C.G.; Lu, Y.C.; Luo, C.; Hu, G.H.; Liu, H.M.; Chen, J.X.; Han, H.X. Expression of ubiquitin-conjugating enzyme E2C/UbcH10 in astrocytic tumors. Brain Res. 2008, 1201, 161-166. [CrossRef]

21. Donato, G.; Iofrida, G.; Lavano, A.; Volpentesta, G.; Signorelli, F.; Pallante, P.L.; Berlingieri, M.T.; Pierantoni, M.G.; Palmieri, D.; Conforti, F.; et al. Analysis of UbcH10 expression represents a useful tool for the diagnosis and therapy of astrocytic tumors. Clin. Neuropathol. 2008, 27, 219-223. [CrossRef]

22. Jiang, L.; Bao, Y.; Luo, C.; Hu, G.; Huang, C.; Ding, X.; Sun, K.; Lu, Y. Knockdown of ubiquitin-conjugating enzyme E2C/UbcH10 expression by RNA interference inhibits glioma cell proliferation and enhances cell apoptosis in vitro. J. Cancer Res. Clin. Oncol. 2010, 136, 211-217. [CrossRef] [PubMed]

23. Lu, J.; Gu, X.; Liu, F.; Rui, Z.; Liu, M.; Zhao, L. Antitumor effects of hsa-miR661-3p on non-small cell lung cancer in vivo and in vitro. Oncol. Rep. 2019, 41, 2987-2996. [CrossRef] [PubMed]

24. Perrotta, I.; Bruno, L.; Maltese, L.; Russo, E.; Donato, A.; Donato, G. Immunohistochemical Analysis of the Ubiquitin-conjugating Enzyme UbcH10 in Lung Cancer: A Useful Tool for Diagnosis and Therapy. J. Histochem. Cytochem. 2012, 60, 359-365. [CrossRef] [PubMed]

25. Pallante, P.; Malapelle, U.; Berlingieri, M.T.; Bellevicine, C.; Sepe, R.; Federico, A.; Rocco, D.; Galgani, M.; Chiariotti, L.; Sanchez-Cespedes, M.; et al. UbcH10 overexpression in human lung carcinomas and its correlation with EGFR and p53 mutational status. Eur. J. Cancer 2013, 49, 1117-1126. [CrossRef] [PubMed]

26. Zhao, L.; Jiang, L.; Wang, L.; He, J.; Yu, H.; Sun, G.; Chen, J.; Xiu, Q.; Li, B. UbcH10 expression provides a useful tool for the prognosis and treatment of non-small cell lung cancer. J. Cancer Res. Clin. Oncol. 2012, 138, 1951-1961. [CrossRef] [PubMed]

27. Chen, C.C.; Chang, T.W.; Chen, F.M.; Hou, M.F.; Hung, S.Y.; Chong, I.W.; Lee, S.C.; Zhou, T.H.; Lin, S.R. Combination of multiple mRNA markers (PTTG1, survivin, UbcH10 and TK1) in the diagnosis of Taiwanese patients with breast cancer by membrane array. Oncology 2007, 70, 438-446. [CrossRef]

28. Berlingieri, M.T.; Pallante, P.; Sboner, A.; Barbareschi, M.; Bianco, M.; Ferraro, A.; Mansueto, G.; Borbone, E.; Guerriero, E.; Troncone, G.; et al. UbcH10 is overexpressed in malignant breast carcinomas. Eur. J. Cancer 2007, 43, 2729-2735. [CrossRef] 
29. Wang, C.; Pan, Y.H.; Shan, M.; Xu, M.; Bao, J.L.; Zhao, L.M. Knockdown of UbcH10 enhances the chemosensitivity of dual drug resistant breast cancer cells to epirubicin and docetaxel. Int. J. Mol. Sci. 2015, 16, 4698-4712. [CrossRef]

30. Pallante, P.; Berlingieri, M.T.; Troncone, G.; Kruhoffer, M.; Orntoft, T.F.; Viglietto, G.; Caleo, A.; Migliaccio, I.; Decaussin-Petrucci, M.; Santoro, M.; et al. UbcH10 overexpression may represent a marker of anaplastic thyroid carcinomas. Br. J. Cancer 2005, 93, 464-471. [CrossRef]

31. Lee, J.J.; Foukakis, T.; Hashemi, J.; Grimelius, L.; Heldin, N.E.; Wallin, G.; Rudduck, C.; Lui, W.O.; Höög, A.; Larsson, C. Molecular cytogenetic profiles of novel and established human anaplastic thyroid carcinoma models. Thyroid 2007, 17, 289-301. [CrossRef]

32. Guerriero, E.; Ferraro, A.; Desiderio, D.; Pallante, P.; Berlingieri, M.T.; Iaccarino, A.; Palmieri, E.; Palombini, L.; Fusco, A.; Troncone, G. UbcH10 expression on thyroid fine-needle aspirates. Cancer Cytopathol. 2010, 118, 157-165. [CrossRef] [PubMed]

33. Fujita, T.; Ikeda, H.; Taira, N.; Hatoh, S.; Naito, M.; Doihara, H. Overexpression of UbcH10 alternates the cell cycle profile and accelerate the tumor proliferation in colon cancer. BMC Cancer 2009, 9, 87. [CrossRef] [PubMed]

34. Chen, S.-M.; Jiang, C.-Y.; Wu, J.-Y.; Liu, B.; Chen, Y.-J.; Hu, C.-J.; Liu, X.-X. Rna Interference-Mediated Silencing of Ubch10 Gene Inhibits Colorectal Cancer Cell Growth in Vitro and in Vivo. Clin. Exp. Pharmacol. Physiol. 2009, 37.

35. Li, S.Z.; Song, Y.; Zhang, H.H.; Jin, B.X.; Liu, Y.; Liu, W.B.; Zhang, X.D.; Du, R.L. UbcH10 overexpression increases carcinogenesis and blocks ALLN susceptibility in colorectal cancer. Sci. Rep. 2014, 4. [CrossRef] [PubMed]

36. Cacciola, N.A.; Calabrese, C.; Malapelle, U.; Pellino, G.; De Stefano, A.; Sepe, R.; Sgariglia, R.; Quintavalle, C.; Federico, A.; Bianco, A.; et al. UbcH10 expression can predict prognosis and sensitivity to the antineoplastic treatment for colorectal cancer patients. Mol. Carcinog. 2016, 55, 793-807. [CrossRef]

37. Pellino, G.; Pallante, P.; Malapelle, U.; Ferraro, A.; Bellevicine, C.; Milone, M.; Troncone, G.; Fusco, A.; Selvaggi, F. UbcH10 overexpression is less pronounced in older colorectal cancer patients. Int. J. Colorectal Dis. 2016, 31, 1367-1368. [CrossRef]

38. Berlingieri, M.T.; Pallante, P.; Guida, M.; Nappi, C.; Masciullo, V.; Scambia, G.; Ferraro, A.; Leone, V.; Sboner, A.; Barbareschi, M.; et al. UbcH10 expression may be a useful tool in the prognosis of ovarian carcinomas. Oncogene 2007, 26, 2136-2140. [CrossRef]

39. Zhao, Z.K.; Wu, W.G.; Chen, L.; Dong, P.; Gu, J.; Mu, J.S.; Yang, J.H.; Liu, Y. Bin Expression of UbcH10 in pancreatic ductal adenocarcinoma and its correlation with prognosis. Tumor Biol. 2013, 34, 1473-1477. [CrossRef]

40. Matsumoto, A.; Ishibashi, Y.; Urashima, M.; Omura, N.; Nakada, K.; Nishikawa, K.; Shida, A.; Takada, K.; Kashiwagi, H.; Yanaga, K. High UBCH10 protein expression as a marker of poor prognosis in esophageal squamous cell carcinoma. Anticancer Res. 2014, 34, 955-962.

41. Yang, M.; Qu, Y.; Shi, R.; Wu, X.; Su, C.; Hu, Z.; Chang, Q.; Liu, S.; Pan, G.; Lei, M.; et al. Ubiquitin-conjugating enzyme $\mathrm{UbcH} 10$ promotes gastric cancer growth and is a potential biomarker for gastric cancer. Oncol. Rep. 2016, 36, 779-786. [CrossRef]

42. Kefeli, M.; Yildiz, L.; Celik, H.; Tosun, M.; Karagoz, F. UbcH10 expression in benign, hyperplastic, and malignant endometrial curetted materials: A tissue microarray study. Int. J. Surg. Pathol. 2012, 20, 360-366. [CrossRef] [PubMed]

43. Morikawa, T.; Kawai, T.; Abe, H.; Kume, H.; Homma, Y.; Fukayama, M. UBE2C is a marker of unfavorable prognosis in bladder cancer after radical cystectomy. Int. J. Clin. Exp. Pathol. 2013, 6, 1367-1374. [PubMed]

44. Wang, S.T.; Li, D.Z.; Li, J.M.; Fang, J.; Li, H.Z.; Tong, P.J.; Liu, F.C. Lentivirus-mediated RNA interference targeting $\mathrm{UbcH} 10$ reduces cell growth and invasion of human osteosarcoma cells via inhibition of ki-67 and matrix metalloproteinases. Oncol. Lett. 2015, 9, 2171-2176. [CrossRef] [PubMed]

45. Troncone, G.; Guerriero, E.; Pallante, P.; Berlingieri, M.T.; Ferraro, A.; Del Vecchio, L.; Gorrese, M.; Mariotti, E.; Iaccarino, A.; Palmieri, E.A.; et al. UbcH10 expression in human lymphomas. Histopathology 2009, 54, 731-740. [CrossRef]

46. Xi, H.; Li, L.; Du, J.; An, R.; Fan, R.; Lu, J.; Wu, Y.X.; Wu, S.X.; Hou, J.; Zhao, L.M. Hsa-miR-631 resensitizes bortezomib-resistant multiple myeloma cell lines by inhibiting UbcH10. Oncol. Rep. 2017, 37, 961-968. [CrossRef] 
47. Han, S.S.; Liu, Q.G.; Zhou, Z.Y.; Yao, Y.M.; Song, T.; Zan, X.F.; Sun, H. FAK expression and its clinicopathological significance in hepatocellular carcinoma. J. Xi'an Jiaotong Univ. Medical Sci. 2013, 34, 280-284.

48. Wang, G.; Benasutti, H.; Jones, J.F.; Shi, G.; Benchimol, M.; Pingle, S.; Kesari, S.; Yeh, Y.; Hsieh, L.E.; Liu, Y.T.; et al. Isolation of Breast cancer CTCs with multitargeted buoyant immunomicrobubbles. Colloids Surfaces $B$ Biointerfaces 2018, 161, 200-209. [CrossRef]

49. Hall, C.; Valad, L.; Lucci, A. Circulating tumor cells in breast cancer patients. Crit. Rev. Oncog. 2016, 21, 125-141. [CrossRef]

50. Tabach, Y.; Sakin, I.K.; Buganim, Y.; Solomon, H.; Goldfinger, N.; Hovland, R.; Ke, X.S.; Oyan, A.M.; Kalland, K.H.; Rotter, V.; et al. Amplification of the 20q chromosomal arm occurs early in tumorigenic transformation and may initiate cancer. PLoS ONE 2011, 6, e14632. [CrossRef]

51. Wang, Y.; Lu, P.; Liu, M. Expression of eIF3h in hepatocellular carcinoma and its clinicopathological significance. J. Pract. Oncol. 2017, 32, 345-348.

52. Van Ree, J.H.; Jeganathan, K.B.; Malureanu, L.; Van Deursen, J.M. Overexpression of the E2 ubiquitin-conjugating enzyme $\mathrm{UbcH} 10$ causes chromosome missegregation and tumor formation. J. Cell Biol. 2010, 188, 83-100. [CrossRef] [PubMed]

53. Zhang, J.; Liu, X.; Yu, G.; Liu, L.; Wang, J.; Chen, X.; Bian, Y.; Ji, Y.; Zhou, X.; Chen, Y.; et al. UBE2C is a potential biomarker of intestinal-type gastric cancer with chromosomal instability. Front. Pharmacol. 2018, 9, 847. [CrossRef] [PubMed]

54. Sheffer, M.; Bacolod, M.D.; Zuk, O.; Giardina, S.F.; Pincas, H.; Barany, F.; Paty, P.B.; Gerald, W.L.; Notterman, D.A.; Domany, E. Association of survival and disease progression with chromosomal instability: A genomic exploration of colorectal cancer. Proc. Natl. Acad. Sci. USA 2009, 106, 7131-7136. [CrossRef] [PubMed]

55. Rizvi, S.; Fischbach, S.R.; Bronk, S.F.; Hirsova, P.; Krishnan, A.; Dhanasekaran, R.; Smadbeck, J.B.; Smoot, R.L.; Vasmatzis, G.; Gores, G.J. YAP-associated chromosomal instability and cholangiocarcinoma in mice. Oncotarget 2018, 9, 5892-5905. [CrossRef]

56. Adams, J. Proteasome inhibition in cancer: Development of PS-341. Semin. Oncol. 2001, 28, 613-619. [CrossRef]

57. Palombella, V.J.; Rando, O.J.; Goldberg, A.L.; Maniatis, T. The ubiquitinproteasome pathway is required for

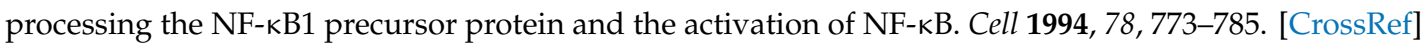

58. Hyer, M.L.; Milhollen, M.A.; Ciavarri, J.; Fleming, P.; Traore, T.; Sappal, D.; Huck, J.; Shi, J.; Gavin, J.; Brownell, J.; et al. A small-molecule inhibitor of the ubiquitin activating enzyme for cancer treatment. Nat. Med. 2018, 24, 186-193. [CrossRef]

59. Harper, J.W.; King, R.W. Stuck in the middle: Drugging the ubiquitin system at the E2 step. Cell 2011, 145, 1007-1009. [CrossRef]

60. Kothayer, H.; Spencer, S.M.; Tripathi, K.; Westwell, A.D.; Palle, K. Synthesis and in vitro anticancer evaluation of some 4,6-diamino-1,3,5-triazine-2-carbohydrazides as Rad6 ubiquitin conjugating enzyme inhibitors. Bioorganic Med. Chem. Lett. 2016, 26, 2030-2034. [CrossRef]

61. Orlicky, S.; Tang, X.; Neduva, V.; Elowe, N.; Brown, E.D.; Sicheri, F.; Tyers, M. An allosteric inhibitor of substrate recognition by the SCF Cdc4 ubiquitin ligase. Nat. Biotechnol. 2010, 28, 733-737. [CrossRef]

62. Pooja Naik, L.C. Diabetes Mellitus and Blood-Brain Barrier Dysfunction: An Overview. J. Pharmacovigil. 2014, 2, 125. [CrossRef] [PubMed]

63. Chan, C.H.; Morrow, J.K.; Li, C.F.; Gao, Y.; Jin, G.; Moten, A.; Stagg, L.J.; Ladbury, J.E.; Cai, Z.; Xu, D.; et al. Pharmacological inactivation of Skp2 SCF ubiquitin ligase restricts cancer stem cell traits and cancer progression. Cell 2013, 154, 556-568. [CrossRef] [PubMed]

64. Sabitha, K.; Rajkumar, T. Identification of small molecule inhibitors against UBE2C by using docking studies. Bioinformation 2012, 8, 1047-1058. [CrossRef] [PubMed]

65. Haynes, B.; Zhang, Y.; Liu, F.; Li, J.; Petit, S.; Kothayer, H.; Bao, X.; Westwell, A.D.; Mao, G.; Shekhar, M.P.V. Gold nanoparticle conjugated Rad6 inhibitor induces cell death in triple negative breast cancer cells by inducing mitochondrial dysfunction and PARP-1 hyperactivation: Synthesis and characterization. Nanomed. Nanotechnol. Biol. Med. 2016, 12, 745-757. [CrossRef] 
66. Malara, N.; Guzzi, G.; Mignogna, C.; Trunzo, V.; Camastra, C.; Della Torre, A.; Di Vito, A.; Lavecchia, A.M.; Gliozzi, M.; Ceccotti, C.; et al. Non-invasive real-time biopsy of intracranial lesions using short time expanded circulating tumor cells on glass slide: Report of two cases. BMC Neurol. 2016, 16, 127. [CrossRef] [PubMed]

67. Simone, G.; Malara, N.; Trunzo, V.; Perozziello, G.; Neuzil, P.; Francardi, M.; Roveda, L.; Renne, M.; Prati, U.; Mollace, V.; et al. Protein-carbohydrate complex reveals circulating metastatic cells in a microfluidic assay. Small 2013, 9, 2152-2161. [CrossRef] [PubMed]

68. Malara, N.; Trunzo, V.; Foresta, U.; Amodio, N.; De Vitis, S.; Roveda, L.; Fava, M.; Coluccio, M.L.; Macrì, R.; Di Vito, A.; et al. Ex-vivo characterization of circulating colon cancer cells distinguished in stem and differentiated subset provides useful biomarker for personalized metastatic risk assessment. J. Transl. Med. 2016, 14, 133. [CrossRef]

69. Guadagno, E.; Presta, I.; Maisano, D.; Donato, A.; Pirrone, C.K.; Cardillo, G.; Corrado, S.D.; Mignogna, C.; Mancuso, T.; Donato, G.; et al. Role of macrophages in brain tumor growth and progression. Int. J. Mol. Sci. 2018, 19, 1005. [CrossRef]

70. Kim, W.T.; Jeong, P.; Yan, C.; Kim, Y.H.; Lee, I.S.; Kang, H.W.; Kim, Y.J.; Lee, S.C.; Kim, S.J.; Kim, Y.T.; et al. UBE2C cell-free RNA in urine can discriminate between bladder cancer and hematuria. Oncotarget 2016, 7, 58193-58202. [CrossRef]

(C) 2020 by the authors. Licensee MDPI, Basel, Switzerland. This article is an open access article distributed under the terms and conditions of the Creative Commons Attribution (CC BY) license (http://creativecommons.org/licenses/by/4.0/). 